\title{
Colourful speleothems in the Wieliczka Salt Mine
}

\author{
Zbigniew SAWŁOWICZ ${ }^{1, *}$, Jerzy PRZYBYŁO² and Konrad BOROŃ ${ }^{1}$ \\ 1 Jagiellonian University, Institute of Geological Sciences, Oleandry 2A, 30-063 Kraków, Poland \\ 2 Wieliczka Salt Mine, Department of Geology, Park Kingi 1, 32-020 Wieliczka, Poland
}

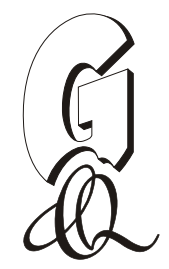

Sawłowicz, Z., Przybyło, J., Boroń, K., 2014. Colourful speleothems in the Wieliczka Salt Mine. Geological Quarterly, 58 (3): 449-458, doi: 10.7306/gq.1155

\begin{abstract}
Secondary halite deposits in the Wieliczka Salt Mine are represented by various forms of speleothems. Some of them, e.g. stalactites, cauliflowers or crusts, reveal various hues, yellow to red to brown. These hues are related to iron compounds, but the forms, occurrence and composition of these compounds has not previously been studied. To explain the origin of their colours a detailed study of samples collected in the mine, including brines and water soluble extracts and produced experimentally in the laboratory, has been undertaken using SEM, XRD and AAS. The colourful speleothems are compared, using SEM-EDS, with the forms and composition of rusting metal artefacts, where several iron oxide minerals have been identified. We suggest that coloured halite is generally pure halite of which the surface was covered by a ferric minerals suspension in the brine. Colours of the speleothems stem from the various colours of iron minerals whereas their intensity is related probably to the type of fluid that coated the crystals, a continuous film or finely dispersed micron-size mineral aggregates.
\end{abstract}

Key words: halite, speleothem, Wieliczka Salt Mine, iron minerals, colours.

\section{INTRODUCTION}

Construction of each underground mine results in changes of the orogenic tensions and hydrogeologic relations, formation of new empty spaces, intensive air movement, etc., all of which enhance development of various and locally ubiquitous forms of speleothems. Visitors to the Wieliczka Salt Mine underground workings in southern Poland are often bewildered by unusual forms and colours of speleothems, mainly of halite but also of some other minerals which are either related to the rocks hosting salts or anthropogenic rusting metal artefacts. Secondary deposits (term limited here to minerals formed after the opening of the mine) in the Wieliczka Salt Mine are very rich and vary, both in scale (from microns to metres) and mineral composition (halite, calcium sulphates, complex sulphates and chlorides, calcium carbonates, iron oxides and hydroxides). The Internet is full of beautiful photographs of speleothems from the Wieliczka Salt Mine, commonly very colourful. These formations were first described, including their genesis, in 1843 in an elegant work of Felix Boczkowski, Imperial and Royal salt physicist. Additional records can be found in the works of Maślankiewicz (1965), Długosz (1975) and Pawlikowski (2009). Recently more detailed description of speleothems appeared in a new album on the Wieliczka Salt Mine (Kowalczyk and Sawło-

\section{* Corresponding author: zbigniew.sawlowicz@uj.edu.pl}

Received: August 21, 2013; accepted: March 17, 2014; first published online: March 25, 2014 wicz, 2013). In most cases, in terms of morphology or genesis, the dripstone formations from mines and caves do not differ significantly, this is why in providing their description, it is possible to apply speleological terminology, e.g. speleothems. Karst in carbonate rocks is very common and has been extensively discussed in multiple publications, whereas karst in salt rocks is both far rarer and less known, despite beautiful descriptions from Israel (Frumkin, 1994) and Iran (Bosák et al., 1999). A short review of literature on various secondary halite deposits in caves can be found in the monograph dedicated to caves (Hill and Forti, 1997). The best description of such deposits has been provided for the Iranian salt karst in a contemporary work by Filippi et al. (2011). Dripstone forms in the Wieliczka Salt Mine are very similar to those found in karst. Formation of halite speleothems generally is related to various inflows of saline brines. Secondary minerals form on anything: rocks, wood or metal fragments, and on a shore or on a bottom of small lakes. Their formation may depend on several different environmental factors, e.g. concentration and composition (admixtures) of brine, flow type (still layer of brine, splash, gravitational or capillary forces), rate and frequency of flow, rate of evaporation, air (aerosol) movement direction, air pressure and humidity.

Colourful natural salts were noted already in antiquity in "The Histories" by Herodotus who described houses in Libya built of both purple and white salts. Pure halite is colourless but in nature it can be discoloured by:

- inclusions of interstitial matter;

- impurities;

- structural defects in the crystal lattice (Sonnefeld, 1995).

Even small admixtures can substantially change its colour. Manganese, gold, silver, lead, iron, copper, chromium, nickel, chrysocolla, clay particles, humic acids, and even microorgan- 
isms (e.g., Halobacteria), impart various hues: pale red, purple, pink, blue, yellow, white, grey, and even black (e.g., Friend and Allchin, 1940; Gaweł, 1947; White, 1997). Also radiation, related to the presence of radioactive potassium ${ }^{40} \mathrm{~K}$, can cause intensive blue or purple hues (e.g., Beynen et al., 2001).

Yellow-red-brown halite is typically attributed to the presence of iron minerals pigments, mainly hematite (e.g., Richter, 1962, 1964; Urai and Boland, 1985) but a deeper knowledge of minerals and forms of occurrence, especially using modern analytical techniques, is surprisingly lacking. Colourful speleothems from the Wieliczka Salt Mine, related usually to iron compounds, are described in detail and the origin of their colours is discussed here. Detailed characteristics of iron compounds occurring on the halite speleothems was not possible, mainly due to the insufficient amount of material. Thus, these iron minerals were compared, based on their colour, morphology and general composition, using SEM-EDS, to minerals in adjacent rusting metal artefacts.

\section{GEOLOGICAL SETTING}

The Wieliczka rock salt deposit is part of the massive salt deposits in the Central European Paratethys basins. Halite deposits are limited to a small area along the northern rim of the Carpathians, the eastern part of the Carpathian foreland (Garlicki, 1979, 2008 with references therein; Fig. 1). It was formed in the Miocene Epoch, approximately 13.6-13.8 Ma (Dudek et al., 2004; de Leeuw et al., 2010; cf. Bukowski et al., 2010) as a result of sedimentation in the Carpathian Foredeep Basin (e.g., Oszczypko et al., 2006; Peryt, 2006 with references therein). The Middle Miocene sediments in Wieliczka include the following formations: Skawina Beds - marly claystones with mudstone and sandstone inserts, Wieliczka Beds - sulphate and chloride evaporites with sandstones and claystones, and
Chodenice Beds - claystones and mudstones interspersed with banks of brittle sandstone. To the south, the Wieliczka deposit borders the Carpathian flysch formations.

The Wieliczka rock salt was deposited over the period of at least twenty thousand years (Garlicki, 1968). It stretches lengthwise almost 10 kilometres and its width extends from several hundred metres to $1.5 \mathrm{~km}$. It is located at the depth from approximately 30 to $330 \mathrm{~m}$ below the surface of land. The deposit is composed of two different units - an autochthonous unit (the lower) and an overthrust one (the upper) (Fig. 2). The lower part, called the stratiform deposit, is built of layers of rock salt interbedded with layers of gangue - claystones, mudstones and sandstones. It is folded and forms three main thrust nappes. The upper part is called the boulder deposit. It is built of blocks of green rock salt, irregularly interspersed in gangue rocks, so called zubers (Bukowski, 2011 with references therein).

\section{MATERIAL AND METHODS}

More than a hundred samples of yellow-red-brown speleothems were collected in various underground galleries. For detailed examination twenty samples were chosen, based on their forms and variation in colours. Morphology and chemical composition of ten raw samples were analysed using a scanning electron microscope with field-emission Hitachi S 4700, equipped with an energy dispersive spectrometry (EDS) Noran Vantage analytical system, operated at an accelerating voltage of $20 \mathrm{kV}$. Samples were coated with carbon to increase conductivity. A "standardless" calculation procedure using standards from the software library was used to evaluate the chemical composition. Because the analysed samples showed very heterogeneous and uneven surface morphologies, the chemical composition reported may differ from the real values. Analyses were performed in the Laboratory of Field Emission Scanning

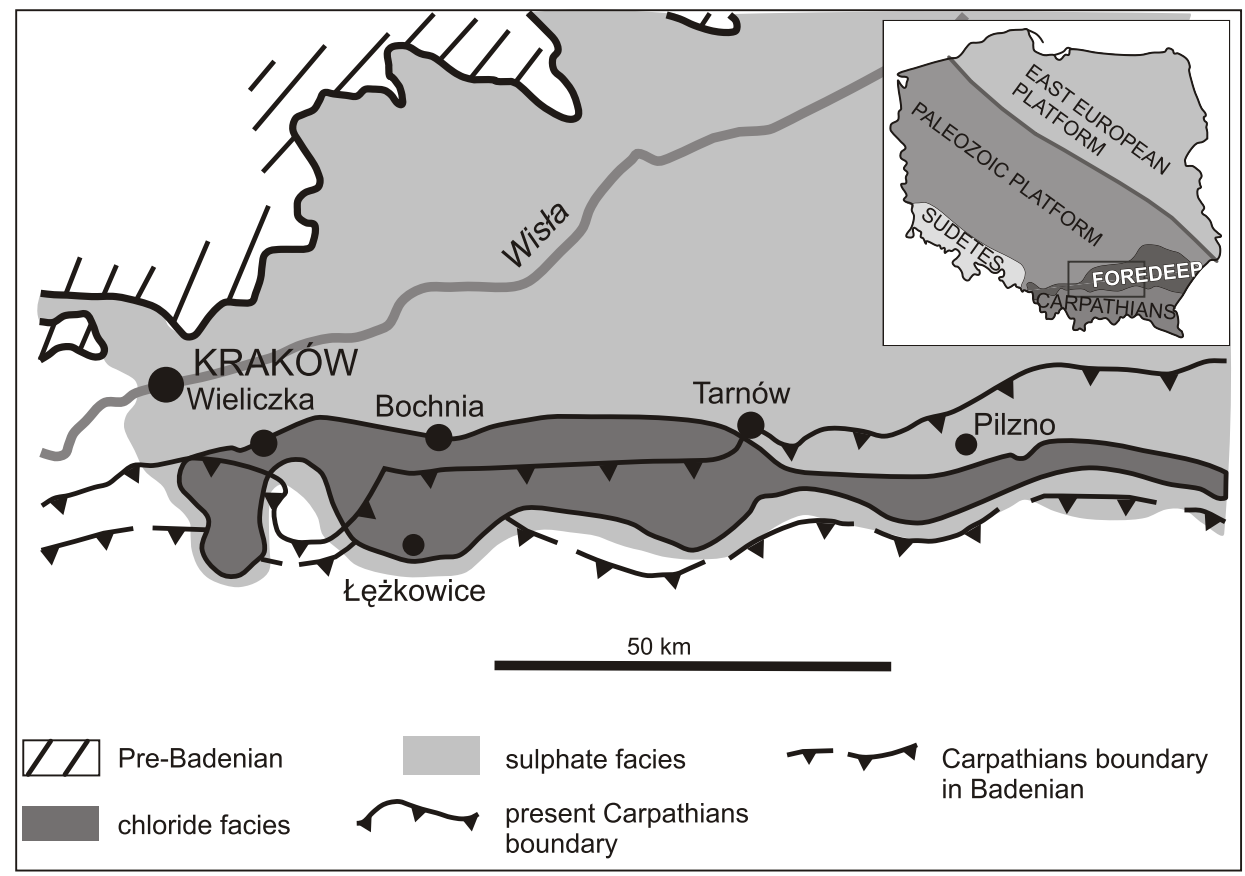

Fig. 1. Distribution of the Miocene evaporites in Kraków vicinity (after Garlicki, 1979, modified) 


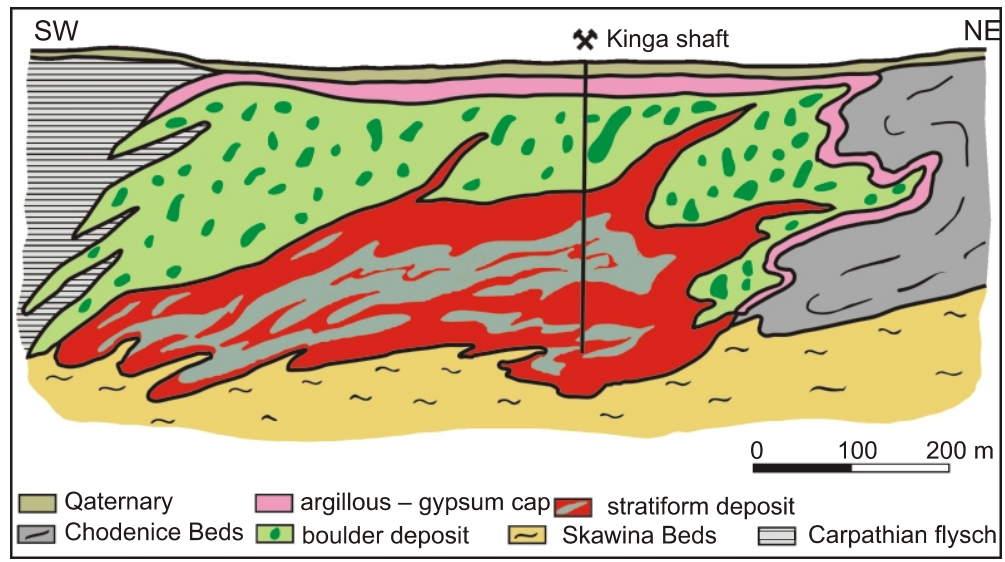

Fig. 2. Simplified cross-section through the Wieliczka Salt Mine deposit in the Kinga shaft area (after Poborski and Skoczylas-Ciszewska, 1963, simplified)

Electron Microscopy and Microanalysis at the Institute of Geological Sciences, Jagiellonian University, Kraków.

Five fragments (2-3 g each) of differently coloured halite speleothems, after cleaning with methanol in an ultrasonic device, were dissolved in distilled water. The water extracts were analysed by atomic absorption spectrometry (AAS) and the mineral residues by X-ray diffraction (XRD). AAS analyses of filtered water extracts and a brine from the Wieliczka Salt Mine were performed by F-AAS (Fe, $\mathrm{Mn}, \mathrm{Ca}, \mathrm{Mg}$ ) and F-AES (K) on a PU9100X spectrophotometer (Philips), and by titration $\left(\mathrm{NH}_{4}\right.$, $\mathrm{NO}_{3}, \mathrm{HCO}_{3}$, and $\mathrm{SO}_{4}$ ). The XRD studies of eight samples with the strongest hue and of residues after water dissolution were carried out using Philips X'Pert X-ray diffractometer ADP with a graphite monochromator, using $\mathrm{Cu}-\mathrm{K} \alpha$ radiation. The measuring range was $4-80^{\circ} 2 \theta$. Interpretation of the spectra was performed using Philips X'Pert Graphics software and the American Mineralogist Crystal Structure Database (http://rruff.geo.arizona.edu/AMS/ amcsd.php).

Simple laboratory experiments on halite crystallisation in the presence of iron were performed. Two iron plates, one clean and one rusty, were submerged in the brine solutions for the period of 8 weeks. Reaction products were studied using SEM-EDS.

\section{RESULTS}

The Wieliczka Salt Mine halite speleothems are generally colourless, either clear or milky. Much more rare but very beautiful and characteristic colourful dripstone formations can be found practically anywhere in the mine on all exploitation levels. Within the dripstones strong variations in hue and intensity are observed very locally, on the scale of centimetres to metres (Figs. 3A-C and 4C, D). Their occurrence is mainly where leakages of brine come in close contact with rusting artefacts (Fig. 3C, D), however, they were also found where no direct relationship between brine and rusting metal was observed. The yellow-red hue was registered practically in all types of speleothems occurring in Wieliczka (Kowalczyk and Sawłowicz, 2013): soda straws, stalactites, stalagmites, stalagnates, flowstones; cave popcorn; idiomorphic crystals; and shrubby, bulbous or finger-like dripstones (Figs. 5A, B; 6B, D and 7A). There is only one exception - St. Kinga's hairs have never been observed coloured, even when they were growing from rusting metal pipes (Fig. 6A). Several samples of the various forms of speleothems in the Wieliczka Salt Mine, ranging in colour from translucent white to yellow to red and to brown, have been studied in detail.

Powder XRD analyses of the darkest yellow-red forms of speleothems showed only the presence of halite. XRD patterns of the residues of halite dissolution showed mainly peaks from aragonite. Presence of the strongest individual peaks characteristic for quartz and calcite suggests the occurrence of these minerals in two residues. No peaks from iron minerals were found, possibly due to insufficient amounts and/or amorphous character.

Chemical analyses were done for the brine and samples of the speleothems, selected for variation in their colours. The brine (WA) comes from the leakage at the level III, close to the Rorańcza drift, draining the upper levels. The leakage is partly collected in a rusting metal container (Fig. 4A). The brine sprinkles the walls of the container and the surrounding salt rock, the wooden board (laying across the container) and the wooden pillar where various forms of secondary halite mineralisation, like coatings, hoppers and stalactites, form (Fig. 4C, D). Fifty metres from there, colourful crusts, stalactites and small cauliflowers occur on the roof of the underground gallery (WB; Fig. 4B). These forms are slightly aligned, perhaps due to local tectonics. No patterns were found between occurrence of dark brown, sometimes almost black, and white forms (Figs. 4D and 6D). The brine (WA), water extracts from the secondary halite close to the rusting container (WA2, WA4 and WA5) and from the roof (WB1 and WB2) were analysed for their chemical composition (Table 1). The brine, except of high $\mathrm{NaCl}$ content, is according to Polish norms (Dz. U. Nr 32, poz. 284, 2004) an unremarkable underground water, with the content of anions typical for class II-IV and of cations typical for class V. Content of $\mathrm{K}^{+}$is relatively high. Contents of cations in the water extracts from the halite speleothems are generally low and there is no correlation between the amount of cations, especially iron, and the colours of the speleothems.

Observations of the coloured halite crystals in the micro-scale (SEM-EDS) were done mainly on the surface of speleothems but in some cases the cross-sections were also studied. Mainly iron minerals were observed in yellow-red samples. In some samples local admixtures of gypsum, aragonite and iron sulphates were also found. Practically no clay minerals were recorded. The hue, from yellow to red-brown, depends on the presence of various iron oxides and hydroxides, first and foremost on the halite surface. In case of a discontinuous growth of a speleothem, laminae, differentiated through changing colour, are observed (Fig. 6C). The iron compounds occur of two forms: dispersed loose aggregates and continuous coatings (Figs. 7 and 8A, B). The dispersed aggregates of iron minerals have globular, spherical, fibrous, and random forms and are composed of isometric, fibrous, or platy crystals (Figs. 9B-D and 10). The coating composed of iron oxides frequently forms a continuous flowstone (5-20 $\mu \mathrm{m}$ thick) on the surface of halite crystals, with cracks resembling desiccation structures (Fig. 9A). The surface of this layer is smooth, whereas underneath it is composed of acicular, fibrous or globular forms (Fig. 8C, D) of similar chemical composition. EDS allows only a general determination of chemical composition of iron oxides and hydroxides. Based on the morphology, the chemical composition and the similarities to iron minerals (lepidocrocite, goethite, akaganéite, hematite, and magnetite) found in the rusty layers on iron artefacts in the Wieliczka Salt Mine (Malinowski et al., 2010; Malinowski and Sawłowicz, 2013) we suggest that some of these iron oxides oc- 

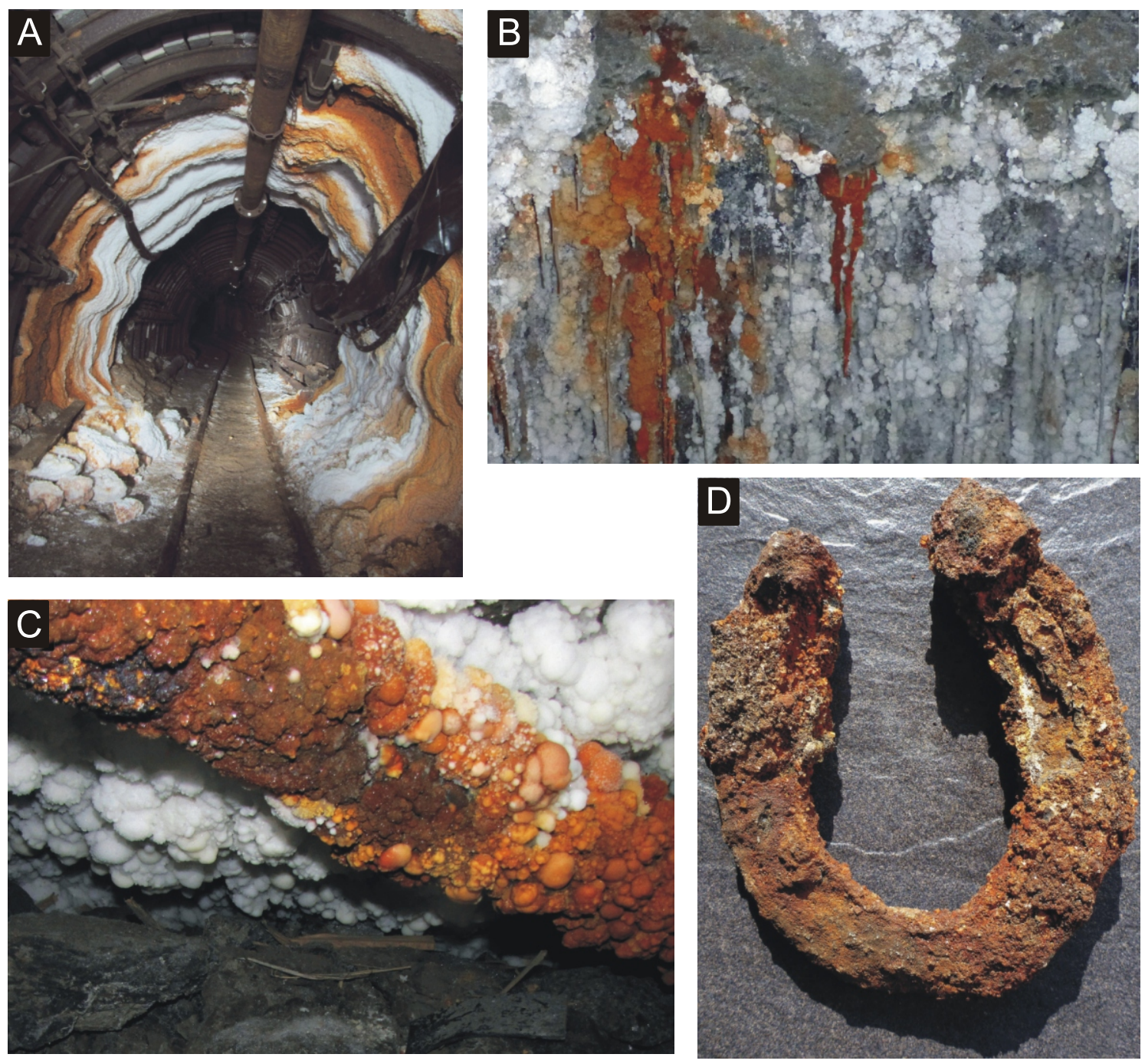

Fig. 3A-massive colourful halite speleothems on the $\measuredangle P$ type metal arch lining in the gallery when a huge leakage of brine took place (photo width $=3.5 \mathrm{~m}$ ); $\mathrm{B}$ - halite stalactites and straws, variably painted with iron compounds, hanging from the gallery roof (photo width $=140 \mathrm{~cm}$ ); $\mathrm{C}-$ white halite cauliflowers on the gallery roof and colourful cauliflowers on the rusting pipe (photo width $=50 \mathrm{~cm}$ ); D - strongly corroded horseshoe belonging to a horse working in the mine in the 19th and 20th centuries

cur on the surface of halite speleothems. EDS chemical analyses show that the volume proportions of these minerals vary significantly from sample to sample and no simple relationship between the hue and the mineral composition can be established. However, some indications can be recognized:

- yellow-orange forms are composed mainly of goethite and akaganéite, possibly also lepidocrocite;

- red and red-brown - mainly of goethite and hematite;

- grey-brown contain mainly hematite, goethite and, locally probable, magnetite.

In laboratory experiment strongly interlaced euhedral halite crystals formed on both plates, in each case with a very low $\mathrm{Fe}$ content. Moreover, in the beaker with the rusty plate (Fig. 8B), a thin ferrous crust, several microns thick, formed on the surface of the brine at the contact with the plate, with the structure and composition very similar to those formed naturally on halite crystals in the Wieliczka Salt Mine.

\section{DISCUSSION}

Halite speleothems in the Wieliczka Salt Mine are typically colourless (transparent) or white (milky). The white colour can be due to several factors: various orientations of very small crystals, numerous liquid and gaseous inclusions, and finally very small and dispersed inclusions of other minerals, e.g. aragonite. To date no detailed study of the white speleothems has been done. Locally dripstone halite formations of varied hues (yellow to red to brown) and intensity are quite common. These colours are related to the ubiquitous presence of iron in the mine. Oxidized iron compounds originate from two sources: 1) clays and sandstones of the Wieliczka host rocks, rich in iron minerals, and 2) corroding metals fragments, common in the mine. The variety of metal products in the Wieliczka Salt Mine, their composition and their designed use are vast. Metal had already been encountered there at the beginning of the subterra- 

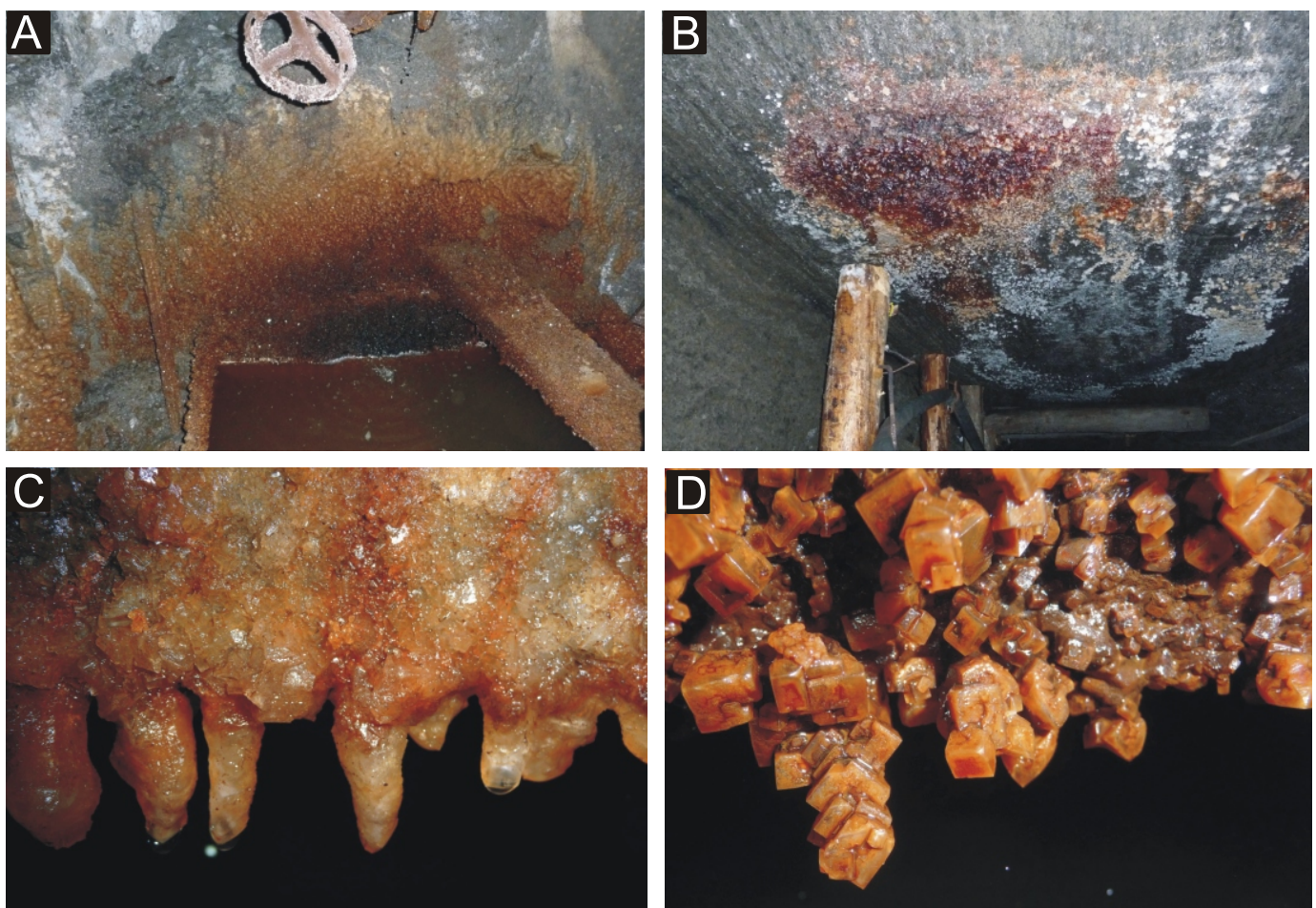

Fig. 4A - a metal container, collecting brine from the leakage, with a wooden board laying across it, both covered by halite speleothems of various hues (photo width $=120 \mathrm{~cm}$ ); B - small halite forms of various colours (stalactites, crystals, cauliflowers) hanging from the gallery roof (photo width $=150 \mathrm{~cm}$ ); C colourful halite stalactites growing downwards from the edge of the wooden board over the iron container with a brine (photo width $10 \mathrm{~cm}$ ); D - colourful idiomorphic halite crystals growing downwards from the lower surface of the wooden board over the iron container with a brine (photo width $=8 \mathrm{~cm}$ )
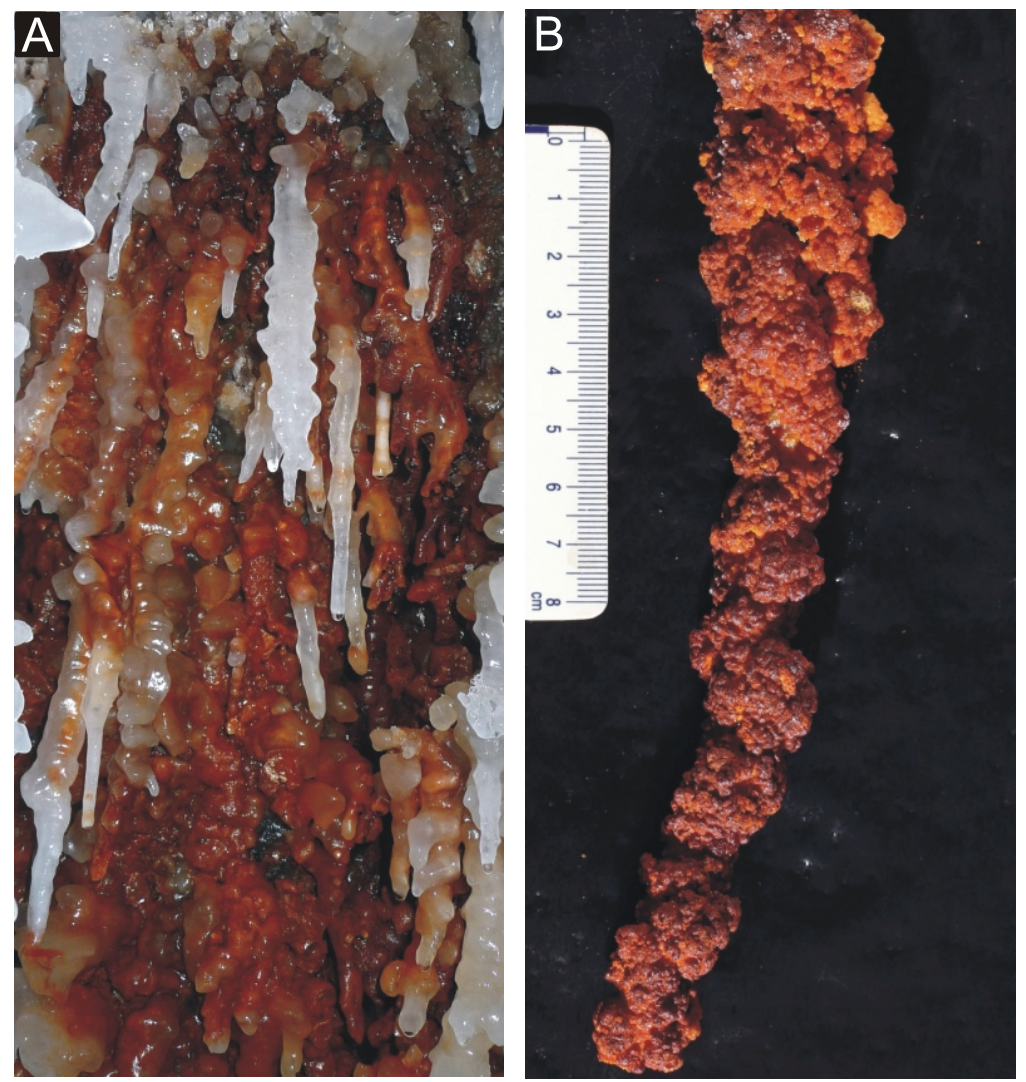

Fig. 5A - active halite stalactites of various colours; B - halite stalactite, completely covered by iron oxides and hydroxides 
Chemical composition of the brine and the halite speleothems water extracts

\begin{tabular}{|c|c|c|c|c|c|c|c|c|c|c|c|}
\hline Sample & Unit & $\mathrm{Fe}^{2+}$ & $\mathrm{Mn}^{2+}$ & $\mathrm{Mg}^{2+}$ & $\mathrm{Ca}^{2+}$ & $\mathrm{K}^{+}$ & $\mathrm{Sr}^{2+}$ & $\mathrm{NH}_{4}^{-}$ & $\mathrm{NO}_{3}^{-}$ & $\mathrm{HCO}_{3}^{-}$ & $\mathrm{SO}_{4}^{2-}$ \\
\hline $\begin{array}{l}\text { Leachate brine } \\
\text { WA }-\mathrm{pH}=7.15\end{array}$ & $\mathrm{mg} / \mathrm{dm}^{3}$ & 3.20 & 1.53 & 461 & 766 & 219 & nd & 0.16 & 62 & 427 & 423 \\
\hline $\begin{array}{l}\text { Halite coating on wood } \\
\text { WA2 yellow }\end{array}$ & $\mathrm{mg} / \mathrm{dm}^{3}$ & 0.06 & 0.01 & 0.24 & 21.6 & 0.77 & 0.55 & nd & nd & nd & nd \\
\hline $\begin{array}{l}\text { Halite coating on metal } \\
\text { WA4 dark brown }\end{array}$ & $\mathrm{mg} / \mathrm{dm}^{3}$ & 0.08 & 0.01 & 0.20 & 10.1 & 0.85 & 0.32 & nd & nd & nd & nd \\
\hline $\begin{array}{l}\text { Halite stalactite } \\
\text { WB1 dark brown }\end{array}$ & $\mathrm{mg} / \mathrm{dm}^{3}$ & 0.01 & 0.01 & 0.66 & 9.36 & 0.99 & 0.34 & nd & nd & nd & nd \\
\hline $\begin{array}{l}\text { Halite cauliflower } \\
\text { WB2 white to yellow }\end{array}$ & $\mathrm{mg} / \mathrm{dm}^{3}$ & 0.02 & 0.02 & 0.51 & 28.2 & 1.15 & 0.37 & nd & nd & nd & nd \\
\hline
\end{tabular}

nd - not determined
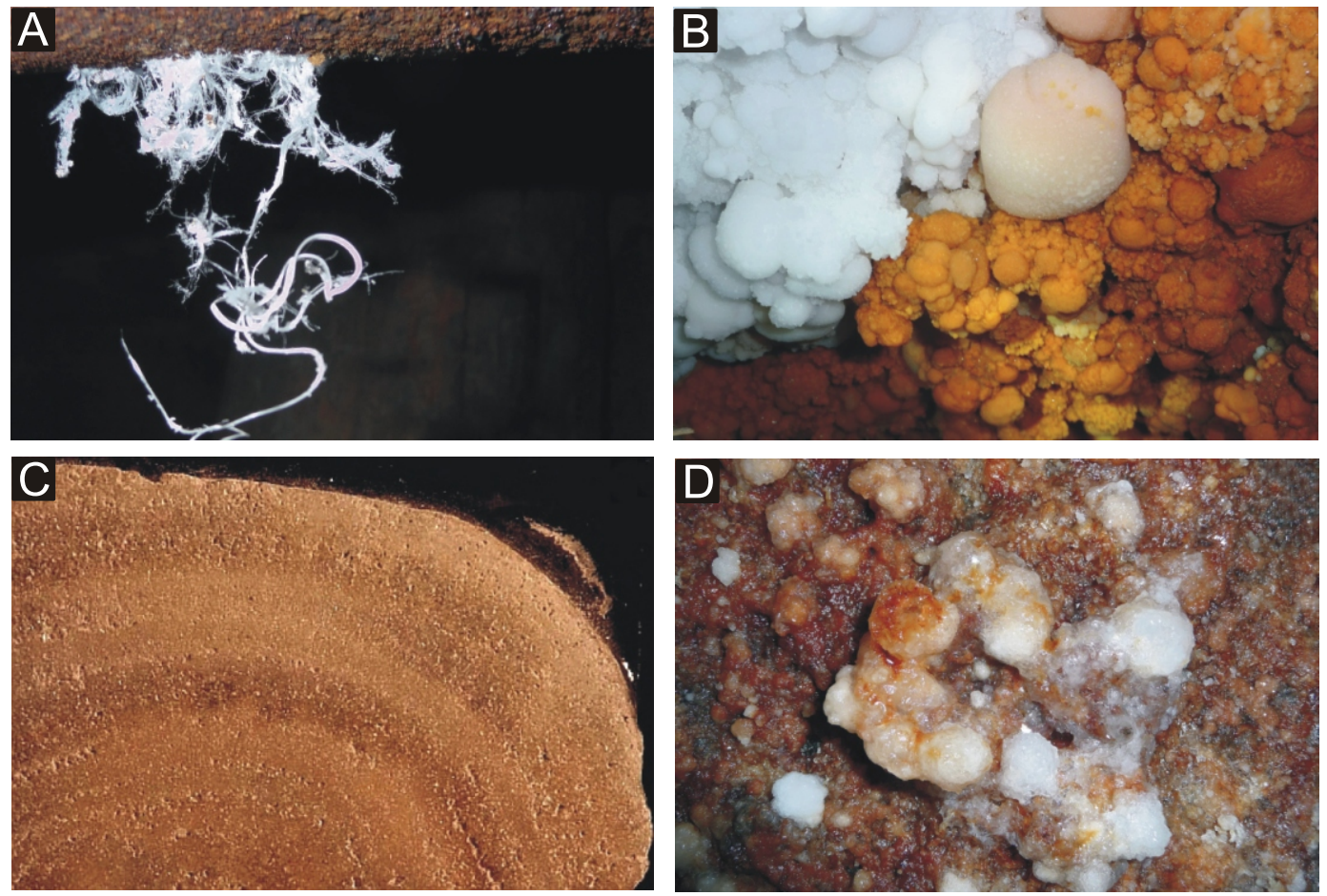

Fig. 6A - white St. Kinga's halite hairs hanging from the rusted metal pipe (photo width $=25 \mathrm{~cm}$ ); $\mathrm{B}$ - halite cauliflower forms of various colours (photo width $=15 \mathrm{~cm}$ ); $\mathrm{C}$ - the cross-section of a cauliflower halite speleothem with various iron-rich layers (photo J. Kowalczyk; photo width $=5 \mathrm{~cm}$ ); D - small halite cauliflowers and crusts on the gallery roof, seen on the Figure 4B (photo width $=10 \mathrm{~cm}$ )
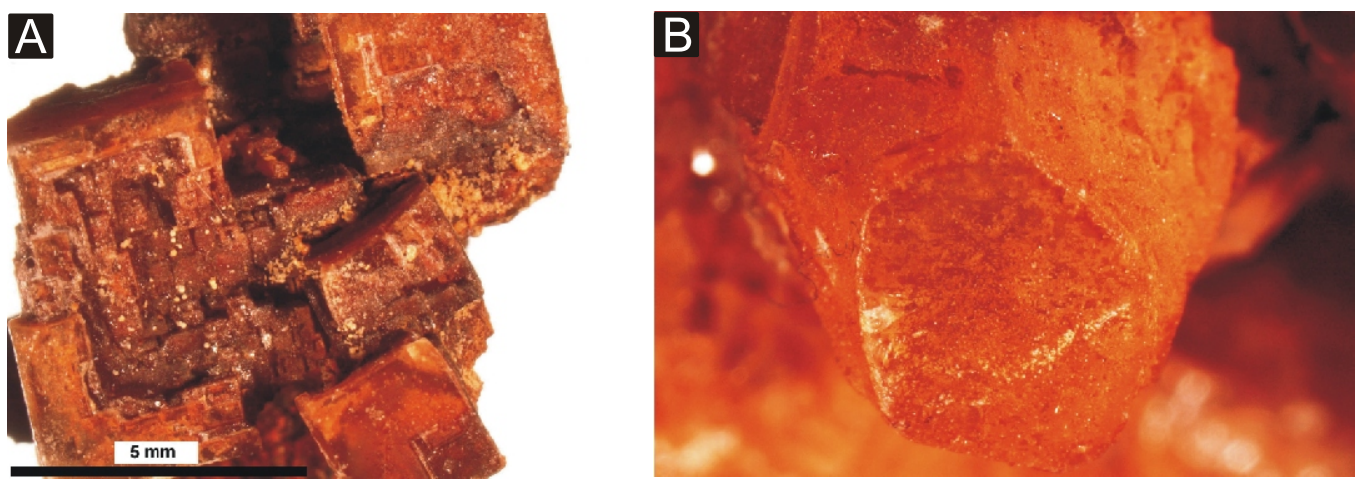

Fig. 7A - magnified view of the halite hopper crystals from the Figure 4D; B - semi-transparent orange halite crystal - note tiny aggregates of $\mathrm{Fe}$ oxides and hydroxides locally on the surface (photo width $=2 \mathrm{~cm}$ ) 

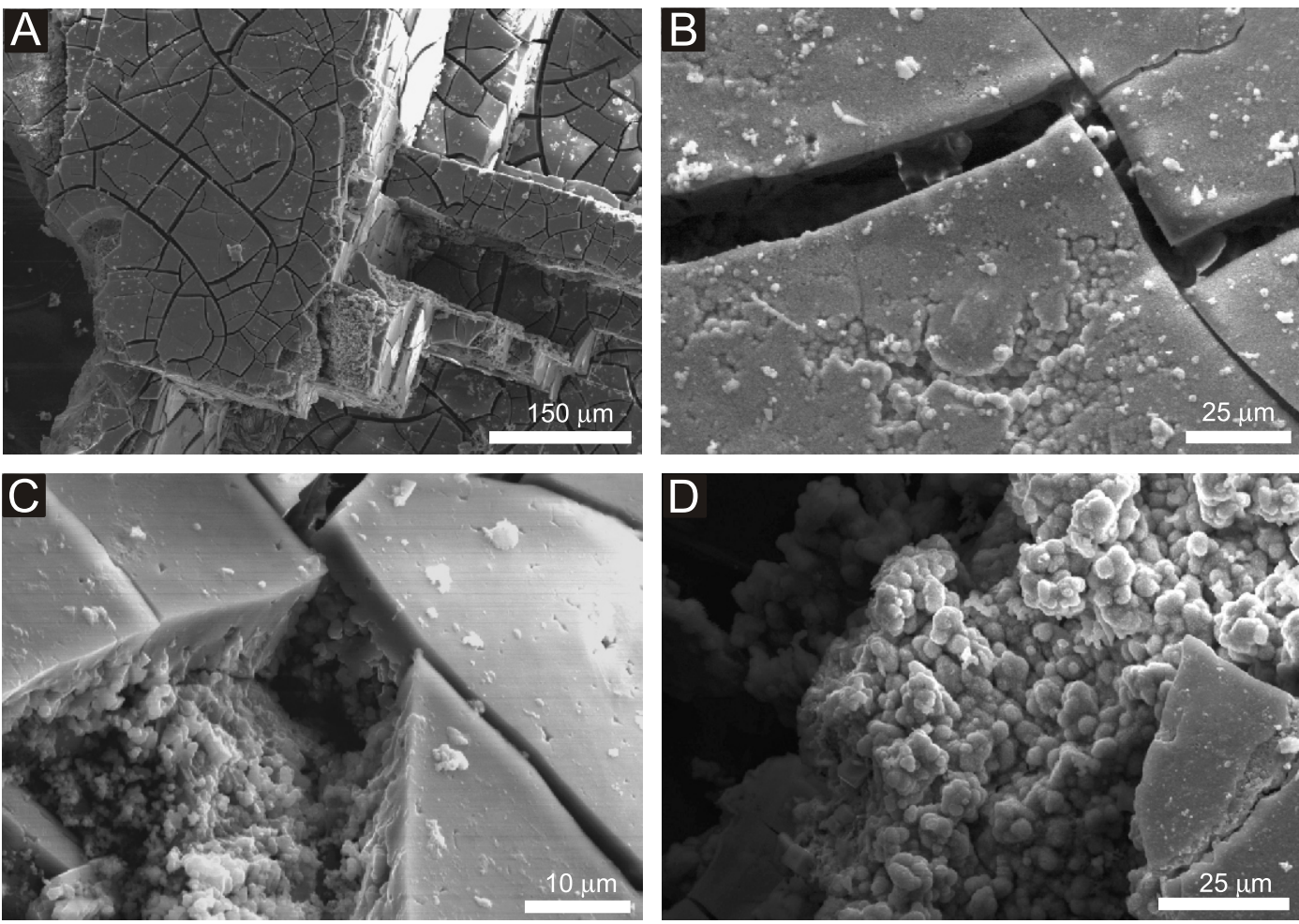

Fig. 8A - smooth layer composed of iron oxides and hydroxides on the surface of halite crystals, with shrinkages probably from drying (SEM); B - smooth layer composed of globular aggregates of iron oxides and hydroxides on the brine surface at the contact with rusty plate (experiment) (SEM); C - side view of the smooth ferrous layer on the surface of halite crystal - note fine grains of similar chemical composition (SEM); D - globular aggregates of iron minerals dispersed on the halite crystal (SEM)

nean exploitation of the deposit but most of the studied rusted artefacts are from 19-20th centuries. Occurrence of speleothems of various colours close to each other and to corroding metals suggests that the latter are the most common source of speleothem colouring. Lack of detailed studies of both corrosion processes and colourful speleothems in the Wieliczka Salt Mine has not allowed interpretation of the origin of various colours until now. Recently, using SEM-EDS, XRD, FTIR and MS, several oxides and hydroxides of iron have been identified in the rust on iron artefacts: akaganéite, hematite, goethite, lepidocrocite and magnetite (Malinowski et al., 2010; Malinowski and Sawłowicz, 2013). Similar mineral compositions of corrosion products have been described from chloride-rich environments by Balasubramaniam et al. (2003) and Antunes et al. (2003). The actual mineralogical composition can differ from those of primary precipitates. For example, the goethite formation is most probably related to the process of dissolution and reprecipitation of earlier corrosion products, lepidocrocite most likely (Raman et al., 1986). These iron oxides might be responsible for specific colours of both the corrosion products and speleothem surfaces, e.g. black - magnetite, orange - goethite and akaganéite, and brown and grey-brown goethite. However, it should be remembered that in most cases we deal with a mixture of several minerals and specific minerals can reveal quite different colours. On the other hand, there is probably a relationship between composition of iron minerals and colour of the studied halite speleothems.

Halite of various colours was described both from the acid and the neutral lakes. Acid halite tends to contain abundant iron oxide minerals, such as hematite, both as solid inclusions and as solids within fluid inclusions whereas neutral halite contains no iron oxides (Benison and Goldstein, 2002; Jagniecki and Benison, 2010). The $\mathrm{pH}$ of infiltration waters in the Wieliczka Salt Mine is generally neutral (6.74-8.15; Winid, 2013) and a typical brine found in the Wieliczka Salt Mine have only a few ppm of $\mathrm{Fe}$ and $\mathrm{Mn}$. Thus, does not seem to influence the colours of the secondary halite forms and we should not expect the presence of iron in the solution or oxide minerals as inclusions inside secondary halite speleothems, as is observed. It should also be stressed that the formation process of the colourful iron-rich halite speleothems differs significantly from that observed in the lakes as halite speleothems are covered with iron mineral-rich brine only from time to time during their growth and/or afterwards and not submerged. Local introduction of the oxidised iron compounds into the brines significantly changes the colour of secondary halite. A relationship between iron and yellow-red halite forms has been noted in many papers, both from the Wieliczka Salt Mine and from other deposits, but the mechanisms responsible have not been described in detail. The present observations, made under natural and laboratory conditions, show that the colours from yellow to redbrown are mainly a result of the presence of various iron oxides and hydroxides, occurring in different ways on the halite surface. Depending on the continuity of the precipitation process of different forms of speleothems the iron minerals can be distributed more or less homogeneously, forming laminae richer in $\mathrm{Fe}$ or coating the surface of speleothems. Iron compounds, released either from corroding iron artefacts or surrounding Fe-containing sedimentary rocks (clays, sandstones) into the brine probably form an aqueous suspension. The first source seems to dominate as there is commonly a close spatial relationship between rusting metal and rusty halite speleothems. 

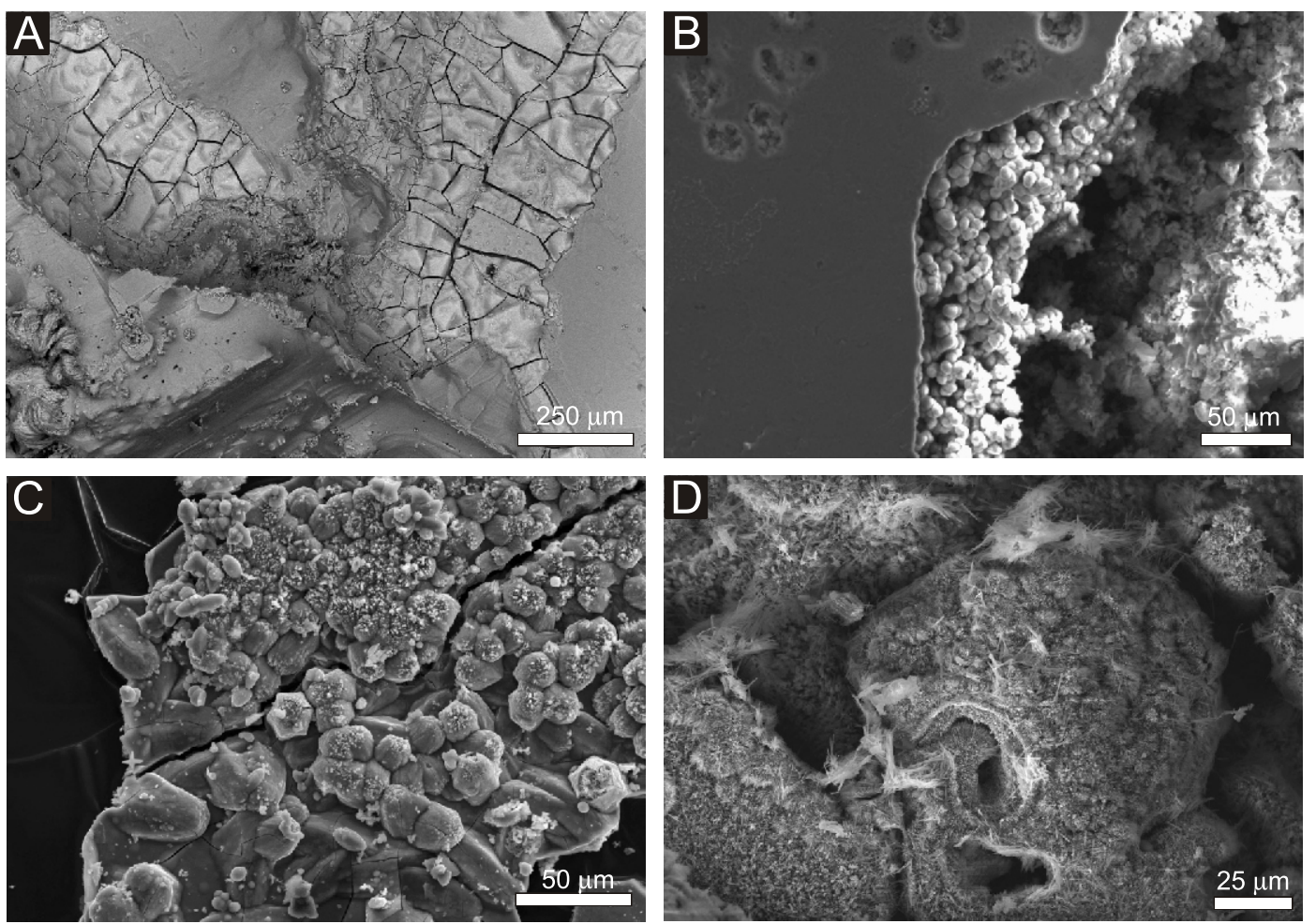

Fig. 9A - layers of iron oxides and hydroxides with characteristic shrinkages from drying, locally being overgrown by secondary halite crust (SEM BSE); B - upper smooth surface with the globular forms of the iron oxides and hydroxides, growing on the surface of brine, next to the rusting metal plate, in the laboratory experiment (SEM); C - globular forms of the iron oxides and hydroxides on the surface of dark halite speleothem (SEM); D - magnified view of some forms from the photo C (SEM) (photo $t$. Malinowski)
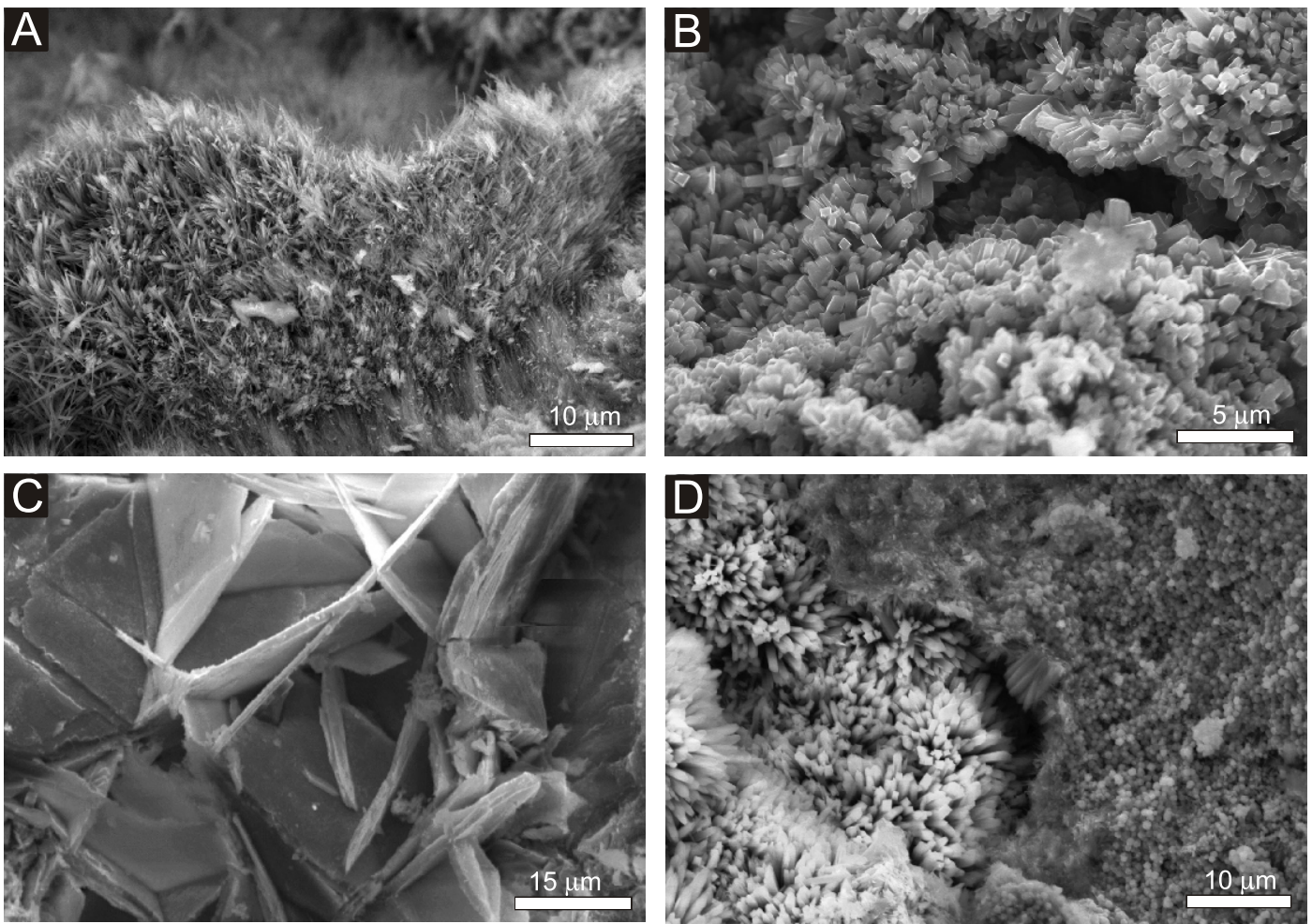

Fig. 10A - akaganéite/goethite fibrous crystals (SEM); B - fibrous crystals of akaganéite/goethite (SEM); C - blady crystals of lepidocrocite (SEM); D - fine granules of magnetite (right) and fibrous crystals of akaganéite/goethite (SEM) (all photos $Ł$. Malinowski) 
The quantities of dissolved iron are scant, which is not surprising as under the oxidising conditions iron $\left(\mathrm{Fe}^{3+}\right)$ is practically insoluble (at $\mathrm{pH}>3$ ). The low concentration of dissolved iron is also confirmed by the observation that practically only pure halite was detected in St. Kinga's hairs (even those on rusted pipe) which are growing by capillary action and are never covered by secondary minerals from the flowing brine. Coloured halite is generally pure halite the surface of which was covered by ferric minerals suspended in the brine. If the composition of brine alternates from pure to Fe-rich during the speleothem growth, we observe colour zonation in the speleothem crosssection. The mineral composition and the size, thickness, and continuity of mineral concentrations of iron seem to control the colour of the halite speleothems. The intensity of the colour depends probably on the type of coating on the crystals. In the case of a continuous film, we suggest that halite crystals were covered with a colloid, water with the suspension of microscopic particles of oxidized iron compounds which later re-crystallised on the halite surface as a result of evaporation, possibly coupled with salination of the colloid. This hypothesis seems to be confirmed by the shrinkages which could form during the drying out process. The smooth surface is most probably a result of the surface tension of an iron-bearing sol. Finely, dispersed micron-size mineral aggregates on the halite surface could give a less intense colour. They can be a result of evaporation of the layer of suspension with a smaller content of iron compounds or evaporation of aerosol micro-drops of similar composition.

Bacteria are quite common both in recent and ancient salt deposits (e.g., McGenity et al., 2000). Namyslowski (1913) found that brines in Wieliczka Salt Mine were teeming with halophilic microorganisms but no bacterial-like forms have been described there since that time. They were also not sought in this work. Nevertheless, a role for bacteria in the transport and deposition of iron compounds in speleothems cannot be excluded, as there are quite a few examples of the relations between bacteria and iron in evaporitic systems. Lowenstein et al. (2011) described the pink/red modern and ancient halite deposits containing halophilic prokaryotes and eukaryotes, some of which were alive inside fluid inclusions. The colour was due to the carotenoids used by microorganisms for protection from ultraviolet radiation. Nanocrystalline Fe oxide minerals, dominated by ferrihydrite, occurring together with the filaments of the iron precipitating bacteria Leptothrix sp. and Gallionella sp., were also described from the Pautler Cave (Frierdich and Catalano, 2009). Similar bacterial forms were found in active iron oxides stalactites from some other North American caves (Peck, 1986) and the limonitic fossilized bacterial remains were found in the ocher unit of the Sandia Cave (Haynes and Agogino, 1986). Hunting bacteria in the Wieliczka Salt Mine is now in progress.

\section{CONCLUSIONS}

The colourful speleothems are related mainly to the rusting metal artefacts. Their colours usually result from coating of their surface by ferric minerals suspended in the brine. Depending on the continuity of the precipitation process the different forms of iron oxides and hydroxides are distributed more or less homogeneously. Various colours of iron minerals give the specific hues of the speleothems whereas the intensity of the colour probably depends on the type of fluid coating crystals. In the case of a continuous film with smooth surface, which is most probably a result of the surface tension of an iron-bearing sol, the hue is deeper. The hue is less intense in the case of finely dispersed micron-size mineral aggregates.

Acknowledgments. Our sincere thanks go to J. Kowalczyk and $\measuredangle$. Malinowski whose help during collection of samples and further laboratory studies was indispensable. Two anonymous reviewers are thanked for their constructive comments and T. Peryt is thanked for the profound editorial. Help of the Wieliczka Mine authorities (President K. d'Obyrn and Chief Geologist K. Brudnik) is also acknowledged. Sally Sutton is sincerely thanked for the very effective discussion on English text.

\section{REFERENCES}

Antunes, R.A., Costa, I., Defaria, D.L.A., 2003. Characterization of corrosion products formed on steels on the first months of atmospheric exposure. Materia, 8: 27-34.

Balasubramaniam, R., Ramesh Kumar, A.V., Dillmann, P., 2003. Characterization of rust on ancient Indian iron. Current Science, 85: 1546-1555.

Benison, K.C., Goldstein, R.H., 2002. Recognizing acid lakes and groundwaters in the rock record. Sedimentary Geology, 151: 177-185.

Beynen, P. van, Bourbonniere, R., Ford, D., Schwarcz, H., 2001 Causes of colour and fluorescence in speleothems. Chemical Geology, 175: 319-341.

Boczkowski, F., 1843. On Wieliczka as Regards Natural History, History, and Baths Baths (in Polish). Nakładem i drukiem Wawrzyńca Pisza w Bochni.

Bosák, P., Bruthans, J., Filippi, M., Svoboda, T., Smid, D.J., 1999. Karst and caves in salt diapirs, SE Zagros Mts. (Iran). Acta Carsologica, 28: 41-75.

Bukowski, K., 2011. Badenian saline sedimentation between Rybnik and Dębica based on geochemical, isotopic and radiometric research (in Polish with English summary). Dissertations Monographs, 236.
Bukowski, K., de Leeuw, A., Gonera, M., Kuiper, K.F., Krzywiec, P., Peryt, D., 2010. Badenian tuffite levels within the Carpathian orogenic front (Gdów-Bochnia area, Southern Poland): radioisotopic dating and stratigraphic position. Geological Quarterly, 54 (4): 449-464.

de Leeuw, A., Bukowski, K., Krijgsman, W., Kuiper, K.F., 2010. Age of the Badenian salinity crisis; impact of Miocene climate variability on the circum-Mediterranean region. Geology, $\mathbf{3 8}$ : 715-718.

Długosz, A., 1975. Cracow Saltworks Museum. Cracow Saltworks Museum. Wieliczka.

Dudek, K., Bukowski, K., Wiewiórka, J., 2004. Radiometric dating of Badenian pyroclastics from Wieliczka and Bochnia (in Polish). Materiały VIII Ogólnopolskiej Sesji Naukowej "Datowanie Minerałów i Skał", Kraków: 18-19.

Filippi, M., Bruthans, J., Palatinus, L., Zare, M., Asadi, N., 2011. Secondary halite deposits in the Iranian salt karst: general description and origin. International Journal of Speleology, 40: 141-162.

Friend, J.N., Allchin, J.P., 1940. Colloidal gold as a colouring principle in minerals. Mineralogical Magazine, 25: 584-596. 
Frierdich, A.J., Catalano, J.G., 2009. Nanocrystalline iron and manganese oxide deposits in Pautler Cave: implications for heavy metal transport and sequestration in a shallow karst aquifer. 2009 Geological Society of America Annual Meeting, October 18th-21st, Portland, OR, USA. http://karstconservancyofillinois.org/pdf/GSA_Poster_Portland09_Frierdich_Final.pdf

Frumkin, A., 1994. Hydrology and denudation rates of halite karst. Journal of Hydrology, 162: 171-189.

Garlicki, A., 1968. Sedimentological investigations of the profile of the autochthonous saliferous formation in the area of Wieliczka and Bochnia (in Polish with English summary). Rocznik Polskiego Towarzystwa Geologicznego, 38: 219-223.

Garlicki, A., 1979. Sedimentation of the Miocene salts in Poland (in Polish with English summary). Prace Geologiczne, 119: 1-66.

Garlicki, A., 2008. Salt Mines at Bochnia and Wieliczka. Przegląd Geologiczny, 56: 663-669.

Gaweł, A., 1947. Geological conditions for the origin of blue salt, ametyst and violet fluorite (in Polish with English summary). Rocznik Polskiego Towarzystwa Geologicznego, 17: 39-60.

Haynes, C.V. Jr., Agogino, G.A., 1986. Geochronology of Sandia Cave. Smithsonian Contributions Anthropology, 32: 1-32.

Hill, C., Forti, P., 1997. Cave Minerals of the World. National Speleological Society. Huntsville, AL, USA.

Jagniecki, E.A., Benison, K.C., 2010. Criteria for the recognition of acid-precipitated halite. Sedimentology, 57: 273-292.

Kowalczyk, J., Sawłowicz, Z., 2013. The fairytale world of dripstone formations. In: The Treasure. Wieliczka Salt Mine (ed. A. Nowakowski): 83-98. Universitas, Kraków.

Lowenstein, T.K., Schubert, B.A., Timofeeff, M.N., 2011. Microbial communities in fluid inclusions and long-term survival in halite. GSA Today, 21: 4-9.

Malinowski, Ł., Sawłowicz, Z., 2013. Metal and its fate. In: The Treasure. Wieliczka Salt Mine (ed. A. Nowakowski): 99-114. Universitas, Kraków.

Malinowski, Ł., Sawłowicz, Z., Przybyło, J., 2010. Mineralogical and geochemical analysis of products of corrosion of iron from the Wieliczka Salt Mine (in Polish with English summary). Geologia, 36: 313-329.

Maślankiewicz, K., 1965. From the History of Salt Mining in Poland (in Polish). WNT, Warszawa.
McGenity, T.J., Gemmeil, R.T., Grant, W.D., Stan-Lotter, H., 2000. Origins of halophilic microorganisms in ancient salt deposits. Environmental Microbiology, 2: 243-250.

Namyslowski, M.B., 1913. Über unbekannte halophile Mikroorganismen aus dem innern des Salzbergwerkes Wieliczka. Bulletin international de l'Académie des sciences de Cracovie, B 3/4: 88-104.

Oszczypko, N., Krzywiec, P., Popadyuk, I., Peryt, T., 2006. Carpathian Foredeep Basin (Poland and Ukraine) - its sedimentary, structural and geodynamic evolution. AAPG Memoir, 84: 293-350.

Pawlikowski, M., 2009. Evaporites. New mineralogical and petrographic data (in Polish with English summary). Geologia, 35: 407-424.

Peck, S.B., 1986. Bacterial deposition of iron and manganese oxides in North American caves. The National Speleological Society Bulletin, 48: 26-30.

Peryt, T.M., 2006. The beginning, development and termination of the Middle Miocene Badenian salinity crisis in Central Paratethys. Sedimentary Geology, 188-189: 379-396.

Poborski, J., Skoczylas-Ciszewska, K., 1963. Miocene in the zone of the Carpathian Overthrust in the area of Wieliczka and Bochnia (in Polish with English summary). Rocznik Polskiego Towarzystwa Geologicznego, 33: 339-347.

Raman, A., Razvan, A., Kuban, B., Clement, K.A., Graves, E., 1986. characteristics of the rust from weathering steels in Louisiana bridge spans. Corrosion, 42: 447-455.

Richter, A., 1962. Die Rotfärbung in den Salzen der deutschen Zechsteinlagerstätten I. Chemie der Erde, 22: 508-546.

Richter, A., 1964. Die Rotfärbung in den Salzen der deutschen Zechsteinlagerstätten II. Chemie der Erde, 23: 179-203.

Sonnefeld, P., 1995. The color of rock salt - a review. Sedimentary Geology, 94: 267-276.

Urai, J.L., Boland, J.N., 1985. Development of microstructures and the origin of hematite in naturally deformed carnallite. Neues Jahrbuch für Mineralogie Monatshefte, (2): 58-72.

White, W.B., 1997. Color of speleothems. In: Cave Minerals of the World, second edition (eds. C. Hill and P. Forti): 239-244. National Speleological Society, Huntsville, AL, USA.

Winid, B., 2013. The study of bromine speciation in water of varying salinity, based on geochemical modeling. Annual Set The Environment Protection, 15: 2452-2467. 